\title{
COMMUNITY PARTICIPATION IN WASTE MANAGEMENT AS A MEDIATION OF THE EFFECT OF REALIGY UNDERSTANDING ON ENVIRONMENTAL CLEANLINESS IN YOUR DISTRICT, DOGIYAI REGENCY, PAPUA
}

\author{
By \\ Ella Adelin Hurulean ${ }^{1}$, Sugiyanto ${ }^{2}$ \\ ${ }^{1,2}$ Sekolah Tinggi Pembangunan Masyarakat Desa “APMD \\ Email: ${ }^{1}$ ellaadelin98@gmail.com,
}

\begin{tabular}{l}
\hline \hline Article Info \\
\hline Article History: \\
Received Nov 13, 2021 \\
Revised Dec 22, 2021 \\
Accepted Jan 24, 2022
\end{tabular}

Keywords:

Understanding Of Religion,

Community Participation And

Environmental Cleanlines

\begin{abstract}
The research entitled Community Participation in Waste Management as Mediating Realistic Understanding of Environmental Hygiene in the Community of Kamu Subdistrict, Dogiyai Regency, Papua aims to determine: 1) religious understanding affects environmental cleanliness 2) community participation affects environmental cleanliness 3) community participation mediates the influence of understanding religion to environmental cleanliness. The population in this study was the entire community of Dogiyai District, Кати District, Dogiyai Regency. The sampling technique used was purposive sampling. The data was obtained by distributing questionnaires to 44 respondents from the Kamu sub-district, Dogiyai district. The data analysis technique in this study is Partial Least Square using the WarpPLS 7.0 application. The results showed that 1) religious understanding had an effect on environmental cleanliness 2) community participation had an effect on environmental hygiene 3) community participation mediated some of the influence of religious understanding on environmental cleanliness
\end{abstract}

Thisisan open accessarticleundertheCC BY-SAlicense.

\section{CorrespondingAuthor:}

Ella Adelin Hurulean

Sekolah Tinggi Pembangunan Masyarakat Desa “APMD

Email: ellaadelin98@gmail.com,

\section{INTRODUCTION}

Waste is generated from human activities in the form of material remnants that are no longer used and then disposed of. Every human activity must produce waste or garbage. The amount or volume of waste is proportional to the level of consumption of goods or materials used daily, Sejati (2009). Each country in the world produces different amounts or volumes of waste, both developed and developing countries such as Indonesia. Indonesia in 2019 became the second largest producer of plastic waste in the world, Indonesia produced around 66-67 million tons of waste in 2019, Permana (2019). For this reason, the government makes a law on waste, as well as programs related to waste to reduce the increase in the amount or volume of waste. Handling of waste is not solely the responsibility of the government, but the participation of the community is also a support so that the plans related to waste that have been made by the government can run well. When planning related to waste management can run well, this will have an impact on environmental cleanliness, community participation is also something that needs to be considered to launch government planning related to waste management. Society is an important part that cannot be separated from the environment. Community participation is community participation in the process of identifying problems and potentials that exist in the community, selecting and making decisions about alternative solutions to deal with problems, implementing efforts to overcome problems, and community involvement in the process of evaluating changes that occur, Adi (2007). Society and the environment are two elements that cannot be separated in a settlement, because these two elements influence each other. The community carries out its activities in an environment, both the built environment and natural environment, and every activity carried out by the community will have an impact/change on the environment. The balance between nature, humans and the built environment will result in a harmonization that will also improve the quality of the environment, Frick (1988). Community participation needs to be considered to determine the success of the system run by the local government regarding 
waste management, community participation can be seen from the level of education and income levels of the community so that it can have an influence on environmental cleanliness in an area, therefore problems related to waste are also not regardless of community participation. Management is a term used in management science. Etymologically, the term management comes from the word to manage and usually refers to the process of managing or handling something to achieve certain goals. So management is a management science that is related to the process of managing and handling something to realize certain goals to be achieved, Nugroho (2003). Waste management is a systematic, comprehensive and sustainable activity that includes waste reduction and handling, Tahupiah et al. (2015). The waste management system in Indonesia has been regulated in Law Number 18 of 2008 concerning Waste Management. The main policy in Law Number 18 of 2008 concerning Waste Management regulates the implementation of integrated and comprehensive waste management, the fulfillment of the rights and obligations of the community, as well as the duties and authorities of the Government and regional governments to carry out public services. The legal regulation of waste management in Law 18 of 2008 concerning Waste Management is based on the principle of responsibility, the principle of sustainability, the principle of benefit, the principle of justice, the principle of awareness, the principle of togetherness, the principle of safety, the principle of security, and the principle of economic value. Poor waste management can have a negative impact on health and the environment as follows, Candra (2006). Therefore, community participation needs to be increased in efforts to handle waste so that it can affect the cleanliness of the environment in an area.

The relationship between humans and the environment is something that cannot be denied, nature provides benefits to humans as well as humans should be able to take care of nature, but in reality there are many deviations committed by humans, in the common life between humans and nature it is necessary to grow a sense of caring for nature, in this case each individual has a different way, understanding related to this can be formed from the religion they have. Every religion teaches that cleanliness is the base of such faith. Elias \& Wattimury (2018) argues that God gives humans the right to control nature and all its contents; so literally, humans are given by God human rights, namely the right to life and the right to freedom. On the other hand, the rights given by God to humans are not used wisely. This can be seen in the lives of people who carry out God's will unwisely which are reflected in human behavior that has a negative impact on environmental quality. Therefore, understanding human religion can have a relationship with the cleanliness of the environment and the natural surroundings.

Dogiyai Regency is regency in Papua Province, Indonesia and was a division of the regency together with 5 other regencies on January 4, 2008 based on Law Number 8 of 2008. There are various kinds of problems related to waste that occur in every region in Indonesia. both in big cities to small areas in Indonesia such as in Dogiyai Regency. In Dogiyai Regency, the agency responsible for handling waste issues is the Environment Agency. The problem of waste is also not spared from the Dogiya district, one of the problems that can be seen is the handling of waste that has not been maximized, until now the Dogiyai district itself does not have a TPA (Final Disposal Site) therefore related to the handling of waste in Dogiyai Regency, the environmental service trying to run several programs, among others:

1) Prepare tools for transporting waste in the form of three-wheeled motorcycles as many as 10 units.

2) Prepare a cleaning workforce of 90 people.

3) Operate TPA

4) Trash collection at Tuka River.

Regarding how the local government of Dogiyai Regency seeks the waste problem, it cannot be separated from good planning and management and its implementation also determines success. There are three religions adhered to in Kab. Dogiyai namely Islam 105, Protestant 13,337 and Catholic 68,433 (Central Bureau of Statistics of Papua Province, 2020), understanding of community religion also determines the success of government efforts in improving environmental cleanliness, apart from that community participation is also an important factor that determines the success of the government related efforts environmental hygiene in Dogiyai Regency.

Based on the above background, this study aims to determine community participation in mediating the effect of religious understanding on environmental cleanliness in the district. You, Kab. dogiyai. Some of the problem formulations in the research are whether community participation mediates the effect of religious understanding on environmental cleanliness?

\section{LITERATURE REVIEW Definition of Waste}

Waste is a material that is wasted or thrown away, is the result of human or natural activities that is no longer used because its main element or function has been taken. Every human activity must generate waste or garbage. Sources of waste can come from households, agriculture, offices, companies, hospitals, markets and so on, Sejati (2009). 
International Journal of Social Science (IJSS)

Vol.1 Issue.5 February 2022, pp: 757-766

ISSN: 2798-3463 (Printed) | 2798-4079 (Online)

DOI: https://doi.org/10.53625/ijss.v1i5.1320

\section{Types of waste}

There are various types of waste which are categorized based on their respective types. Waste is divided into three, namely organic waste, inorganic waste, and B3 waste, Sucipto (2012):

1. Organic Waste Organic waste comes from living things, humans, animals, and plants. Organic waste itself is divided into wet organic waste and dry organic waste. The term wet organic waste means that waste has fairly high water content, such as fruit peels and vegetable residues. Meanwhile, dry organic waste includes other organic materials with small water content, such as paper, wood or tree branches and dry leaves.

2. Inorganic Waste Inorganic waste does not come from living things. This waste comes from renewable materials and hazardous and toxic materials. Types that fall into the category of being able to be recycled include materials made of plastic or metal. Non-metallic dry waste (glass cups, glass bottles, cloth, wood, etc.) as well as soft waste such as dust and ashes.

3. B3 Waste (Hazardous and Toxic Materials) B3 waste is a type of waste categorized as toxic and dangerous for humans. Generally, this type of waste contains mercury such as cans of spray paint or perfume.

However, it is possible that the waste contains other harmful toxins. Sources of waste. There are several sources of waste are as follows. Gelbert, MA, Prihanto \& Suprihatin (1996): 1. Residential waste, namely household waste in the form of food processing residue, used household equipment, paper, cardboard, glass, cloth, garden/yard waste, and others.

3. Agricultural and plantation waste, agricultural activity waste is classified as organic material, such as straw and the like. Most of the waste generated during the harvest season is burned or used for fertilizer. Chemical waste such as pesticides and artificial fertilizers needs special treatment so as not to pollute the environment. Other agricultural waste is a plastic sheet covering the plant area which serves to reduce evaporation and inhibit weed growth, but this plastic can be recycled.

4. Garbage from the rest of the building and building construction. The waste originating from the construction and restoration activities of this building can be in the form of organic or inorganic materials. Organic waste, for example: wood, bamboo, plywood. Inorganic waste, for example: cement, sand, species, bricks, tiles, iron and steel, glass and cans.

5. Garbage from trade and offices. Waste originating from trading areas such as: shops, traditional markets, stalls, supermarkets consists of cardboard, wrapping, paper, and organic materials including food and restaurant waste. Waste originating from educational institutions, government and private offices usually consists of paper, writing utensils (pens, pencils, markers, etc.), photocopy toner, printer ribbons, printer boxes, batteries, chemicals from the laboratory, machine ribbons. typing, movie cliches, broken computers, and so on. Used batteries and chemical waste must be collected separately and must receive special treatment because they are dangerous and toxic.

6. Industrial waste, namely waste originating from the entire series of production processes in the form of chemicals, flakes or pieces of material, as well as treatment and packaging of products in the form of paper, wood, plastic, or rags saturated with solvents for cleaning.

\section{The impact of waste}

One of the negative impacts on the environment is caused by various hazardous and toxic materials (B3) contained in the waste. Garbage is still a problem in Indonesia because the services provided are still relatively limited, H Arif Sumantri (2015).

\section{Waste Management}

1. Definition of Management

Management is a term used in management science. Etymologically, the term management comes from the word to manage and usually refers to the process of managing or handling something to achieve certain goals. So management is a management science that is related to the process of managing and handling something to realize certain goals to be achieved, Nugroho (2003).

2. Waste Management

Waste management is a systematic, comprehensive, and sustainable activity that includes waste reduction and handling, Tahupiah et al. (2015).

The waste management system in Indonesia has been regulated in Law Number 18 of 2008 concerning Waste Management. The main policy in Law Number 18 of 2008 concerning Waste Management regulates the implementation of integrated and comprehensive waste management, the fulfillment of the rights and obligations of the community, as well as the duties and authorities of the Government and regional governments to carry out services. The regulation of waste management in Law 18 of 2008 concerning Waste Management is based on the 
principle of responsibility, the principle of sustainability, the principle of benefit, the principle of justice, the principle of awareness, the principle of togetherness, the principle of safety, the principle of security, and the principle of economic value.

\section{Community participation}

\section{Participation}

Participation is the participation of the community in development, participating in development activities and participating in development activities utilize and enjoy the results of development, Suryono (2001).

Society is a group of people who get along with each other, in scientific terms, they are interacting with each other. A human unit can have infrastructure through which its citizens can interact with each other. Another definition, society is the unity of human life that interacts according to a certain system of customs that is continuous, and which is bound by a sense of shared identity. Continuity is a community unit that has four characteristics, namely: 1) Interaction between its citizens, 2). Customs, 3) Continuity of time, 4) A strong sense of identity that binds all citizens. Koentjaraningrat (2009).

Community participation is community participation in the process of identifying problems and potentials that exist in the community, selecting and making decisions about alternative solutions to deal with problems, implementing efforts to overcome problems, and community involvement in the process of evaluating changes that occur, Adi (2007). Society and the environment are two elements that cannot be separated in a

Settlement, because these two elements influence each other. The community carries out its activities in an environment, both the built environment and the natural environment, and every activity carried out by the community will have an impact / change on the environment. The balance between nature, humans and the built environment will result in a harmonization that will also improve the quality of the environment, Frick (1988).

There are several factors that can affect community participation in an activity. The factors that influence the wisdom of the participating community are divided into two based on Suroso et al. (2014) namely:

a. Internal factors: consist of age, education level, type of work.

b. External factors: consist of communication and leadership.

\section{Understanding Reality}

Society and the environment are two elements that cannot be separated in a settlement, because these two elements influence each other. The community carries out its activities in an environment, both the built environment and the natural environment, and every activity carried out by the community will have an impact / change on the environment. The balance between nature, humans and the built environment will result in a harmonization that will also improve the quality of the environment, Slameto (1995).

Gen (1:23-31): "God said, 'Behold, I give you every herb that has seed on all the earth and every tree that bears seed; that will be your food. But to all the beasts of the earth and to all the birds of the air and to all that creeps on the earth that has life, I give every green plant for food. "And Allah saw all that He had made, it was very good." Elias \& Wattimury (2018) argues that God gives humans the right to control nature and all its contents, so literally, humans are given by God human rights, namely the right to life and the right to freedom. On the other hand, the rights given by God to humans are not used wisely. This can be seen in the lives of people who carry out God's will unwisely which is reflected in human behavior that has a negative impact on environmental quality.

\section{Environmental}

Hygiene Hygiene is creating a healthy environment so that it is not susceptible to various diseases such as diarrhea, dengue fever, vomiting and others. This can be achieved by creating a clean, beautiful and comfortable environment, Buhungo (2012).

1. Environmental hygiene factors Environmental cleanliness

is important and needs attention, this is because the level of cleanliness in an area participates in determining environmental health in the area To determine the high or low level of environmental health in an area can be influenced by several factors among others, namely the central government, local governments, the business world, the community, other related factors, namely the knowledge of the community regarding the importance of environmental health. There are several factors that play a role in health status, both internal and external factors, namely: internal factors consist of physical and psychological factors, external factors consist of various factors such as social, community culture, physical environment, politics, economy, education and so on, Blum (1974) ). There are several factors that affect the cleanliness of the environment in an area, in this study the factors that will be studied related to environmental cleanliness are waste management, education level and community income level and community participation.

\section{Conceptual Framework of}


International Journal of Social Science (IJSS)

Vol.1 Issue.5 February 2022, pp: 757-766

ISSN: 2798-3463 (Printed) | 2798-4079 (Online)

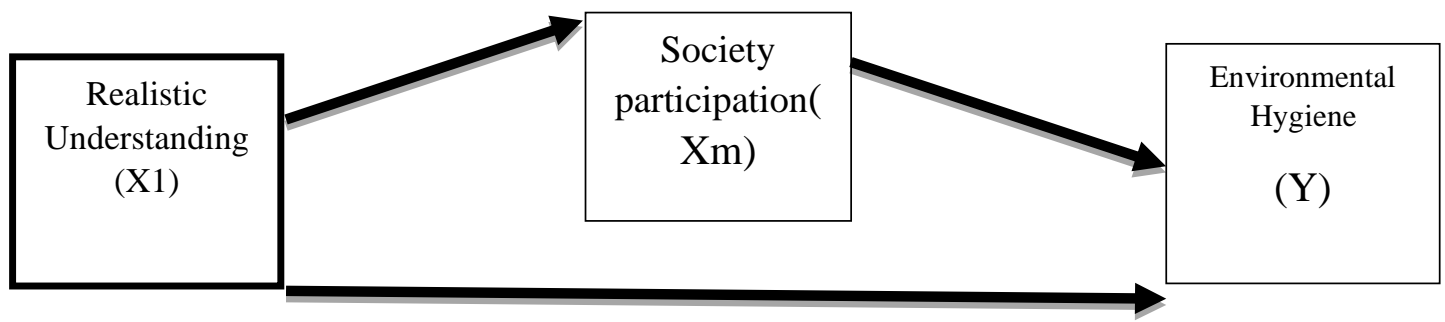

This research is a descriptive study with a qualitative approach. According to Sugyono (2016: 9) qualitative descriptive method is a research method based on the philosophy of postpositivism used to examine the condition of natural objects (as opposed to experiments) where the researcher is the key instrument of data collection techniques carried out by triangulation (combined), data analysis is inductive/qualitative and qualitative research results emphasize meaning rather than generalization.

\section{Population and Sample}

The population in this study is the community of Kec. You, Kab. Dogiyai 107,741 people with a density of more than 500 people per square kilometer in Kec. You, Kab. Dogiyai (Agustinus Goo, 2021) and the research sample was 44 people.

\section{Sampling Techniques The sampling}

Technique used in this research is purposive sampling. The selection of a group of subjects in purposive sampling is based on certain characteristics that are considered to have a close relationship with previously known population characteristics, in other words the sample unit contacted is adjusted to certain criteria that are applied based on the research objectives, Margono ( 2004).

In this study, using the following criteria:

1. Respondents who settled or domiciled in Dogiyai Regency, Papua.

2. Respondents who work, have a family and live at least 5 years in Dogiyai Regency. 3. Respondents with a strong understanding of religion in Dogiyai Regency.

\section{Data Analysis Techniques}

In this study, the data analysis technique used was Partial Least Square (PLS). Partial Least Square (PLS) is factor interdeminacy method of analysis because it does not assume the data must be of a certain scale, the number of samples is small. For prediction purposes, the PLS approach is more suitable. With the PLS approach it is assumed that all variances are variances to explain. Because the approach to estimating latent variables is considered as a linear combination of indicators, it avoids the problem of indeterminacy and provides a definite definition of the score, Ghozali (2014). Data management in this study uses the WarpPLS 7.0 application. The steps that will be used to answer the research problem formulation are:

1. Tabulation of research results into Microsoft Excel.

2. Designing the Measurement Model (Outer Model) The

Outer Model is often also called the (outer relation or meansurement model) defines how each indicator block relates to its latent variable. In principle, it is testing the indicator against the latent variable, or in other words measuring how far the indicator can explain the latent variable. Wiyono (2011).

3. Designing a Structural Model (Inner Model)

and substantive theory) describes the relationship between latent variables based on substantive theory. Inner model or structural model in principle is to test the effect of one variable with other variables, both exogenous and endogenous. It can also be said to test the hypothesis (if the research uses a hypothesis) between one latent variable and another. Wiyono (2011).

\section{RESULT AND DISCUSSION}

\section{Average Extracted (AVE)}

Table 1.1 AVE

\begin{tabular}{|l|l|l|}
\hline Variable & Ave Value & Status \\
\hline Understanding Reality & 0.667 & Valid \\
\hline
\end{tabular}




\begin{tabular}{|l|c|c|}
\hline $\begin{array}{l}\text { Community } \\
\text { Participation }\end{array}$ & 0.706 & Valid \\
\hline Environmental Hygiene & 0.719 & Valid \\
\hline
\end{tabular}

AVE value must be above .0.50. Table 1.1 above shows that religious understanding has a value of 0.667 , community participation has a value of 0.706 and environmental cleanliness is 0.719 so it can be said that the three variables are valid because the AVE value has met the requirements, which is above 0.50.

Reliability Test

Table 1.2 Cronbachs Alpha and Composite Reliability

\begin{tabular}{|l|l|l|l|}
\hline Variable & Cronbachs Alpha & Composite Reliability & Status \\
\hline Understanding & 0.746 & 0.826 & Reliable \\
\hline $\begin{array}{l}\text { Community } \\
\text { Participation }\end{array}$ & 0.798 & 0.856 & Reliable \\
\hline Environmental Hygiene & 0.858 & 0.892 & Reliable \\
\hline
\end{tabular}

The Cronbachs Alpha and Composite Reliability from table 1.2 show that the three variables have Cronbachs Alpha $>0.50$ and Composite Reliability $>0.70$. So the three variables are religious understanding, community participation and reliable environmental hygiene.

R value ${ }^{2}$

Table $1.3 \mathrm{R}_{\text {value }}$

\begin{tabular}{|l|l|}
\hline Variable & Value $\mathbf{R}^{2}$ \\
\hline Community Participation & 0.342 \\
\hline $\begin{array}{l}\text { Environmental } \\
\text { Cleanliness }\end{array}$ & 0.216 \\
\hline
\end{tabular}

From Table 1.3 it is known that $\mathrm{R}^{2}$ community participation variable 0.342 which means $34.2 \%$ of community participation is explained by education level, income level and religious understanding, while the remaining $65.8 \%$ is explained by other variables. outside of research.

The R value $\mathrm{e}^{0.216}$, which means that $21.6 \%$ of environmental cleanliness is explained by education level, income level and religious understanding, while the remaining $78.4 \%$ is explained by other variables outside the study.

Hypothesis Testing
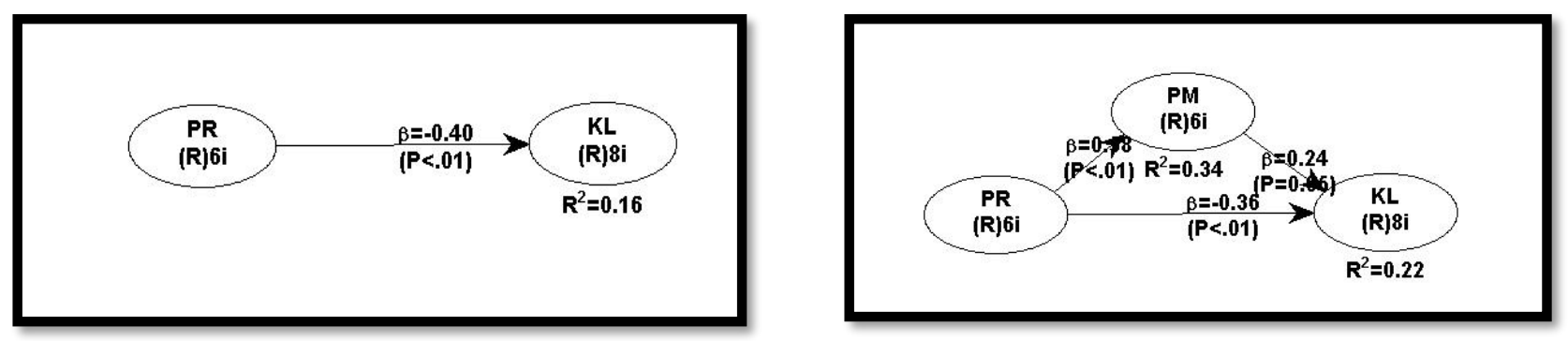

Table 1.4 Direct Effect Estimation Value

\begin{tabular}{|l|l|l|l|}
\hline Hypothesis & Path Coefficients & P-Value & Status \\
\hline PR-KL & -0.402 & 0.002 & Significant \\
\hline
\end{tabular}


International Journal of Social Science (IJSS)

Vol.1 Issue.5 February 2022, pp: 757-766

ISSN: 2798-3463 (Printed) | 2798-4079 (Online)

Table 1.5 Indirect Effect Estimation Value

\begin{tabular}{|l|l|l|l|}
\hline Hypothesis & $\begin{array}{l}\text { Path } \\
\text { Coefficients }\end{array}$ & $\begin{array}{l}\text { P- } \\
\text { Value }\end{array}$ & Status \\
\hline PR-KL & -0.361 & 0.004 & Significant \\
\hline PM-KL & 0.237 & 0.045 & Significant \\
\hline PR-PM & 0.585 & 0.001 & Significant \\
\hline
\end{tabular}

1. Hypothesis Testing 1

a. Hypothesis

$\mathrm{H}_{0}$ : Understanding of religion has no effect on environmental cleanliness.

$\mathrm{H}_{\mathrm{a}}$ : Understanding of religion affects the cleanliness of the environment

b. The basis for decision making

$\mathrm{P}_{\text {valus }} 0.05$, then $\mathrm{H}_{0}$ accepted, $\mathrm{Ha}_{\mathrm{i}}$ rejected.

$\mathrm{P}_{\text {values }} 0.05$, then $\mathrm{H}_{0}$ rejected, $\mathrm{H}_{\mathrm{a}}$ accepted.

c. The decision

$\mathrm{P}_{\text {values }} 0.0040 .05$, then $\mathrm{H}_{0}$ rejected, $\mathrm{H}_{a}$ accepted.

d. Explanation

Religious understanding has an effect on environmental cleanliness, this can be seen in the $\mathrm{P}_{\text {values }}$ which are worth 0.05 . This means that the higher the understanding of religion, the higher the environmental cleanliness and vice versa with an error rate of 5\%.

2. Hypothesis Testing 2

a. Hypothesis

$\mathrm{H}_{0}$ : Community participation has no effect on environmental cleanliness.

$\mathrm{H}_{\mathrm{a}}$ : Community participation has an effect on environmental cleanliness

b. The basis for decision making

$\mathrm{P}_{\text {valus }} 0.05$, then $\mathrm{H}_{0}$ accepted, $\mathrm{Ha}_{\mathrm{i}}$ rejected.

$\mathrm{P}_{\text {values }} 0.05$, then $\mathrm{H}_{0}$ rejected, $\mathrm{H}_{\mathrm{a}}$ accepted.

c. The decision

$\mathrm{P}_{\text {values }} 0.0450 .05$, then $\mathrm{H}_{0}$ rejected, $\mathrm{H}_{\mathrm{a}}$ accepted.

d. Explanation

Religious understanding has an effect on environmental cleanliness, this can be seen in the $\mathbf{P}_{\text {valus }}$ which are worth 0.05 . This means that the higher the understanding of religion, the higher the environmental cleanliness and vice versa with an error rate of 5\%.

3. Hypothesis Testing 3

a. Hypothesis 3

$\mathrm{H}_{0}$ : Understanding of religion has no effect on community participation.

$\mathrm{H}_{a}$ : Understanding of religion has an effect on community participation.

b. The basis for decision making

$\mathrm{P}_{\text {values }} 0.05$, then $\mathrm{H}_{0}$ accepted, $\mathrm{Ha}_{\mathrm{is}}$ rejected.

$\mathrm{P}_{\text {valus }} 0.05$, then $\mathrm{H}_{0}$ rejected, $\mathrm{H}_{a}$ accepted.

c. The decision

$\mathrm{P}_{\text {values }} 0.0010 .05$, then $\mathrm{H}_{0}$ rejected, $\mathrm{H}_{\mathrm{a}}$ accepted.

d. Explanation

Religious understanding has an effect on community participation, this can be seen in the $\mathrm{P}_{\text {values }}$ which are worth 0.05 . This means that the higher the understanding of religion, the higher the community participation and vice versa with an error rate of $5 \%$.

4. Hypothesis Testing 4

a. Hypothesis 4 
$\mathrm{H}_{0}$ : Community participation does not mediate the effect of religious understanding on environmental cleanliness. Ha Community participation mediates the effect of religious understanding on environmental cleanliness.

b. Basis for decision making:

1) If the path coefficients between understanding religion and environmental cleanliness from direct effects (see Table 1.4) to (see Table 1.5) indirect effects, the value does not change and remains significant, then $\mathrm{H}_{0}$ accepted and $\mathrm{Ha}_{\mathrm{is}}$ rejected and no mediation.

2) If the path coefficients between the understanding of religion and environmental cleanliness from direct effects (see Table 1.4) to indirect effects (see Table 1.5) the value decreases and remains significant, then $\mathrm{H} 0$ is srijected $_{\text {and }}$ and $\mathrm{Ha}_{\mathrm{is}}$ accepted by partial mediation. ).

3) If the path coefficients between the understanding of religion and environmental cleanliness from direct effects (see Table 1.4) to indirect effects (see Table 1.5) the value decreases and is not significant, then $\mathrm{H} 0$ is rijected $_{\text {and }}$ and $\mathrm{Ha}_{\mathrm{is}}$ accepted with full mediation. ). c.decisions

Path coefficients on the direct effect between religious understandings of environmental cleanliness are -0.402 down to -0.361 on indirect effects and $P_{\text {valus }}$ remain significant, and the influence of religious understanding on community participation is significant, then $\mathrm{H} 0 \mathrm{is}_{\text {rejected }}$ and accepted. This means that community participation

Partiallymediates influence of religious understanding on environmental cleanliness.

d. Explanation

Public participationPartial mediates the effect of religious understanding on environmental cleanliness. So it can be concluded that community participation plays a role in mediating some (partial mediation) the effect of religious understanding on environmental cleanliness with an error rate of $5 \%$.

Summary of Hypothesis Testing Results

Table 1.6 Hypothesis Testing Results Overall

\begin{tabular}{|l|l|}
\hline Hypothesis & Results \\
\hline $\mathrm{H}_{1}$ & Supported Data \\
\hline $\mathrm{H}_{2}$ & Supported Data \\
\hline $\mathrm{H}_{3}$ & Supported Data \\
\hline $\mathrm{H}_{4}$ & Supported Data \\
\hline
\end{tabular}

Discussion

Religious understanding has an effect on environmental cleanliness.

The results of the research conducted showed that the understanding of religion had an effect on environmental cleanliness. This means that the higher the understanding of religion owned by the community, the higher the environmental cleanliness in Dogiyai district and vice versa. This study is in accordance with the theory put forward by Verkuy in Elias \& Wattimury (2018), namely three ethical theories, namely: 1. Deontological ethics, 2. Teleological ethics and 3. Virtue ethics where there is a relationship between the study of Christian ethics and environmental cleanliness. Therefore, the better the understanding of religion owned by the people of Dogiyai Regency has the effect of being able to improve environmental cleanliness in Dogiyai Regency.

Community participation has an effect on environmental cleanliness.

The results of the research have shown that community participation has an effect on environmental cleanliness. This means that the higher the community participation, the higher the level of environmental cleanliness in Dogiyai Regency. This study is in accordance with research conducted by Pratiwi, Soemirat, and Ainun (2017) which states that there is a relationship between community participation and waste. Therefore, the higher community participation will have an influence on environmental cleanliness in Dogiyai Regency.

\section{Understanding of religion affects community participation}

The results of this study indicate that understanding of religion has an effect on community participation. This means that the higher the understanding of religion, the higher the community participation. This research is in 
International Journal of Social Science (IJSS)

Vol.1 Issue.5 February 2022, pp: 757-766

ISSN: 2798-3463 (Printed) | 2798-4079 (Online)

DOI: https://doi.org/10.53625/ijss.v1i5.1320

accordance with the theory put forward by Verkuy in Elias \& Wattimury (2018), namely three ethical theories, namely: 1. Deontological ethics, 2. Teleological ethics and 3. Virtue ethics where there is a relationship between the study of Christian ethics and community participation. Therefore, the higher the understanding of community religion, the higher community participation and vice versa.

Community participation partially mediates theeffectof religious understanding on environmental cleanliness.

The results of this study indicate that community participation partially mediates theeffect of religious understanding on environmental cleanliness. This means that the higher the understanding of religion, the higher the environmental cleanliness through partial mediation (partial mediation) community participation. This research is in accordance with the research put forward by Elias \& Wattimury (2018) which states that God gives humans the right to control nature and all its contents, so literally, humans are given by God human rights, namely the right to life and the right to freedom. On the other hand, the rights given by God to humans are not used wisely. This can be seen in the lives of people who carry out God's will unwisely which is reflected in human behavior that has a negative impact on environmental quality. In this study, the path coefficients on direct effect between religious understandings of environmental cleanliness were -0.370 down to -0.349 on the indirect effect and $P_{\text {valus }}$ remained significant, and the influence of religious understanding on community participation was significant, so $\mathrm{H}_{\text {was }}$ rejected and $\mathrm{H}_{\mathrm{Ha}}$ accepted.

\section{CONCLUSION}

Based on the results of research that has been carried out by researchers on community participation in waste management as a mediation of the influence of education level, income level and religious understanding on environmental cleanliness, the conclusions obtained are as follows:

1. Understanding religion affects environmental cleanliness

2. Community participation affects cleanliness environment

3. Community participation mediates partly mediates the influence of religious understanding on environmental cleanliness

\section{SUGGESTIONS}

Based on the conclusions of the study, the researcher provides several suggestions which will be submitted as follows: 1. For the Environmental Service of Dogiyai Regency, Papua.

a. Understanding of religion

Based on the results of the study, the average score of the variable understanding of religion which has the smallest statement items compared to other statements "You feel that the wishes made by you are often considered with belief in God" has an average score of 3.68 is in the sufficient category and can still be improved. This means that people have the perception that the wishes made by the community are quite often considered with belief in God and can still be improved. So the research suggests to the Environmental Service to increase community participation in environmental cleanliness so that the goals of the Environmental Service can be achieved, starting with building cooperation with religious leaders (Pastor, Pastor, Ustad) in Dogiyai district so that through the cooperation that exists can increase people's desire for environmental cleanliness.

b. Community participation

Based on the results of the study, the average score of the community participation variable which has the smallest statement items compared to other statements "You feel that your job affects your participation" has an average score of 3.70 which is included in the high category and can still be improved. This means that the community has a perception that the work they have is sufficient to determine the high participation shown or given by the community and can still be improved. So the researchers suggested to the Dogiyai Regency Environmental Service to try to provide understandings and training to the community regarding how to manage waste properly and the benefits obtained by the community because when viewed from the characteristics of the respondents based on the work owned by the community, most of them were farmers and village heads, where The Environment Agency can start training on waste management, such as organic waste that can be processed into compost that is beneficial to the community, and to start it can build cooperation with local village heads regarding plans that will be carried out by the Environmental Service. Environment can be achieved and the local community can also benefit.

\section{REFERENCES}

[1] Adi, I. R. (2007) Intervensi Komunitas Pengembangan Masyarakat Sebagai Upaya Pemberdayaan masyarakat. Jakarta: PT Raja Grafindo Persada.

[2] Agustinus Goo (2021) Upaya Dinas Lingkungan Hidup dalam Mengatasi Problematika Pengelolaan Sampah di Kabupaten Dogiyai Provinsi Papua. 
[3] Badan Pusat Statistik Provinsi Papua (2020) 'Jumlah Penduduk Menurut Kabupaten/Kota dan Agama yang Dianut Di Provinsi Papua (Jiwa), 2020'. Available at: https://papua.bps.go.id/indicator/12/577/1/jumlahpenduduk-menurut-kabupaten-kota-dan-agama-yang-dianut-di-provinsi-papua.htm.

[4] Blum, H. L. (1974) Planning for Health, Development and Aplication of Social Chages Theory. New York: Human Sciences Press.

[5] Buhungo, R. A. (2012) 'Faktor Perilaku Kesehatan Masyarakat dan Kondisi Lingkungan Rumah dengan Kejadian Malaria', E-Journals, Vol.5.

[6] Candra, B. (2006) Pengantar Kesehatan Lingkungan. Jakarta: EGC.

[7] Elias, T. F. E. and Wattimury, W. A. (2018) 'Kajian Etika Kristen terhadap Kebersihan Lingkungan di Kelurahan Klabala', SOSCIED, Vol.1.

[8] Frick, H. (1988) Arsitektur dan Lingkungan. Yokyakarta: Kanisius.

[9] Gelbert, M. A., Prihanto, D. and Suprihatin, A. (1996) Konsep Pendidikan Lingkunga Hidup dan "Wall Chart”. Malang: Buku Panduang Lingkungan Hidup, PPPGT/VEDC.

[10] Ghozali, I. (2014) 'Structural Equation Modeling, Metode Alternatif dengan Partial Least Square (PLS)', in Edisi 4. Semarang: Badan Penerbit Universitas Diponegoro.

[11] H Arif Sumantri (2015) Kesehatan Lingkungan. Jakarta: Kencana Prenada Group.

[12] Koentjaraningrat (2009) Pengantar Ilmu Antropologi. Jakarta: PT Rineka Cipta.

[13] Margono, S. (2004) Metodologi Penelitian Pendidikan. Jakarta: PT Rineka Cipta.

[14] Nugroho (2003) Good Governance. Bandung: Mandar Maju.

[15] Permana, E. (2019) Indonesia Hasilkan 67 juta ton sampah pada 2019, aa.com. Available at: https://www.aa.com.tr/id/headline-hari/indonesia-hasilkan-67-juta-ton-sampah-pada-2019/1373712. (Accessed: 19 February 2021).

[16] Pratiwi, A. F., Soemirat, J. and Ainun., S. (2017) 'Hubungan Partisipasi Masyarakat terhadap Sampah di Kelurahan Sukaluyu', Jurnal Online Institut Teknologi Nasional, Vol.02.

[17] Sejati, K. (2009) Pengelolaan Sampah Terpapu. Yokyakarta: Kanisius.

[18] Slameto (1995) Belajar dan Faktor-Faktor yang Mempengaruhinya. Jakarta: PT Rineka Cipta.

[19] Sucipto, C. D. S. (2012) Teknologi Pengolahan Daur Ulang Sampah. Yokyakarta: Gosyen Publising.

[20] Suroso, H., Hakim, A. and Noor, I. (2014) 'Faktor-faktor yang mempengaruhi partisipasi masyarakat dalam perencanaan pembangunan di Desa Banjaran Kecamatan Driyorejo Kabupaten Gresik', Wacana, Vol.17.

[21] Suryono, A. (2001) Teori dan Isu Pembangunan. Malang: Universitas Malang Press.

[22] Tahupiah, D. M., Rares, J. J. and Ogotan, M. (2015) 'Pengaruh Implementasi Sistem Pengelolaan Sampah Terhadap Peningkatan Kebesihan Lingkungan Di Kecamatan Amurang Barat Kabupaten Minahasa Selatan', Ejournal.unsrat., Vol.4.

[23] Wiyono, G. (2011) Merancang Bisnis dengan Alat Analisis SPSS 17.0 dan Smart PLS 2.0. Yokyakarta: UPP STIM YKPN. 